Article

\title{
Acidic alumina overcoating on platinum nanoparticles: Close metal-acid proximity enhances bifunctionality for glycerol hydrogenolysis
}

\author{
Hongyi Du, Si Chen, Hengwei Wang, Junling Lu* \\ Department of Chemical Physics, Hefei National Laboratory for Physical Sciences at the Microscale, Collaborate Innovation Center of Chemistry for Energy \\ Materials (iChEM), CAS Key Laboratory of Materials for Energy Conversion, University of Science and Technology of China, Hefei 230026, Anhui, China
}

\section{A R T I C L E I N F O}

\section{Article history:}

Received 15 April 2017

Accepted 9 May 2017

Published 5 July 2017

\section{Keywords:}

Metal-acid proximity effect

Hydrogenolysis of glycerol

Platinum catalyst

Atomic layer deposition

Oxide overcoating

\begin{abstract}
A B S T R A C T
Bifunctional catalysts that contain both metal and acidic functions have been widely used in renewable biomass conversions. The bifunctionality closely depends on the distance between the metal and acid sites. However, the metal-acid proximity effect has rarely investigated in biomass conversions. In this work, we precisely deposited a porous $\mathrm{Al}_{2} \mathrm{O}_{3}$ overcoat onto a $\mathrm{Pt} / \mathrm{Al}_{2} \mathrm{O}_{3}$ catalyst using atomic layer deposition to improve the proximity between the Pt metal and the alumina acid sites by increasing the area of the metal-acid interface. Diffuse reflectance infrared Fourier transform spectroscopy (DRIFTS) of pyridine chemisorption confirmed that the overall catalyst acidity did not change considerably after applying the alumina overcoat. In the aqueous-phase, hydrogenolysis of glycerol was used to demonstrate that the alumina overcoat significantly improved the activity approximately 2.8-fold, as well as the selectivity to 1,2-propanediol (1,2-PD) at high conversions. DRIFTS measurements of $\mathrm{CO}$ chemisorption indicated that the Pt-alumina interface had greater area for alumina coated $\mathrm{Pt} / \mathrm{Al}_{2} \mathrm{O}_{3}$ than for the uncoated analog. Moreover, we used the hydrogenation of acetol, the key reaction intermediate in glycerol hydrogenolysis, as a control experiment to confirm that the observed activity improvement in the hydrogenolysis of glycerol could be attributed to the enhancement of the dehydration reaction step, which requires acidic function. In brief, our work provides solid evidence that close metal-acid proximity enhances bifunctionality, thus improving the catalytic activity.
\end{abstract}

(C) 2017, Dalian Institute of Chemical Physics, Chinese Academy of Sciences. Published by Elsevier B.V. All rights reserved.

\section{Introduction}

Bifunctional catalysts, containing metal and acid sites, have been widely employed in fossil fuel hydrocracking and renewable biomass conversions [1-5]. The distance between the two types of sites plays a crucial role in the bifunctionality, which governs the catalytic performance including both activity and selectivity [6-8]. The maximum distance, beyond which cata- lytic activity drops, is the so-called intimacy criterion [6]. The most common way of probing the metal-acid proximity effect is to use a physical mixture of individual catalytic components $[9,10]$, such as $\mathrm{Pt} / \mathrm{SiO}_{2}$ and acidic zeolite, where the Pt metal is dispersed on non-acidic $\mathrm{SiO}_{2}$, and the acid is present in the zeolite particles [11]. In this case, the metal-to-acid site distances are not precisely controlled, varying from the nanometer to even micrometer range. It has been suggested that catalytic

\footnotetext{
* Corresponding author. Tel: +86-551-63600359; E-mail: junling@ustc.edu.cn

This work was supported by the National Natural Science Foundation of China (51402283, 21473169), One Thousand Young Talents Program under the Recruitment Program of Global Experts, and the Fundamental Research Funds for the Central Universities (WK2060030017). DOI: 10.1016/S1872-2067(17)62859-6 | http://www.sciencedirect.com/science/journal/18722067 | Chin. J. Catal., Vol. 38, No. 7, July 2017
} 
performance could be improved by placing the metal and acid sites as close together as possible [12]. For instance, Ryoo et al. [13] reported that Pt nanoparticles (NPs) supported on the external surface of a zeolite particle with a well-controlled thickness allowed better control over distance. They showed that decreasing zeolite crystal thickness to nanosheets significantly improved the product selectivity to branched isomers in the hydroisomerization of $n$-heptane. Meanwhile, Martens and co-workers [14] recently argued that close proximity between metal and zeolite acid sites could be detrimental for cracking large hydrocarbon molecules (such as $n$-decane, and $n$-nonadecane).

Interest in the production of biofuels and chemicals from renewable biomass has been increasing [5]. However, the metal-acid proximity effect has been considerably less extensively explored in biomass conversions compared with fossil fuel hydrocracking [15]. Glycerol, an abundant and inexpensive by-product $(\sim 10 \mathrm{wt} \%)$ of biodiesel production $[5,10,16]$, could be converted into value-added chemicals such as 1,2-propanediol (1,2-PD) and 1,3-propanediol (1,3-PD) via hydrogenolysis [17]. As shown in Scheme 1, glycerol hydrogenolysis involves sequential dehydration and hydrogenation steps on acid and metal sites, respectively [5,17]. It has been proposed that the Lewis acid site attacks the terminal $\mathrm{OH}$ of glycerol to form acetol as an intermediate, while the Brønsted acid site attacks the internal $\mathrm{OH}$ to form 3-hydroxypropanal; next, hydrogenation of acetol or 3-hydroxypropanal takes place at a metal site to produce 1,2-PD and 1,3-PD, respectively [5,17-19]. Therefore, the balance between acid and metal function is critical for effective hydrogenolysis.

Supported noble metal catalysts have been used for glycerol hydrogenolysis [19-26]. Adding acidic function to a metal catalyst could significantly promote the catalytic activity, as the dehydration step requires acid sites (Scheme 1). A number of studies have demonstrated that incorporating acid sites into either metal NPs [19,23,27] or supports [20], or even a simple physical mixture of solid acids and metal catalysts [10], could be effective in improving activity. However, to the best of our knowledge, the metal-acid proximity effect has not been explored.

In this work, we precisely deposited a porous $\mathrm{Al}_{2} \mathrm{O}_{3}$ overcoat onto a Pt/ $\mathrm{Al}_{2} \mathrm{O}_{3}$ catalyst using atomic layer deposition (ALD) by taking advantage of its self-limiting surface reaction feature. Compared with the uncoated $\mathrm{Pt} / \mathrm{Al}_{2} \mathrm{O}_{3}$ catalyst, the porous acidic $\mathrm{Al}_{2} \mathrm{O}_{3}$ overcoat deposited on the Pt improves the proxim-

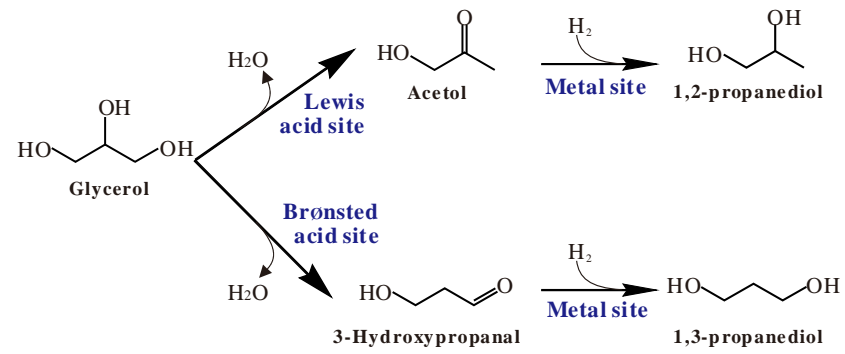

Scheme 1. Hydrogenolysis of glycerol to 1,2-propanediol and 1,3-propanediol over bifunctional catalyst which contains metal and Lewis or Brønsted acid sites. ity between the Pt metal and alumina acid sites by increasing the area of the metal-acid interface, while keeping the overall catalyst acidity constant. This maintained acidity is expected as the overcoat is the same material as the support. This new strategy provides an ideal platform for investigating the metal-acid proximity effect on glycerol hydrogenolysis. Our results suggest that the close metal-acid proximity effect could promote catalyst activity approximately 2.8 -fold, as well as improving selectivity to $1,2-\mathrm{PD}$ at high conversions.

\section{Experimental}

\subsection{Synthesis of $\mathrm{Pt} / \mathrm{Al}_{2} \mathrm{O}_{3}$ catalyst}

The alumina supported Pt catalyst was prepared using the impregnation method [28]. In brief, $2.0 \mathrm{~g}$ of spherical gamma-alumina powder (Nanodur, Alfa Aesar, 99.5\%) was added to an aqueous $\mathrm{H}_{2} \mathrm{PtCl}_{6} 6 \mathrm{H}_{2} \mathrm{O}$ (Sinopharm Chemical Reagent Co., Ltd.) solution $(0.05 \mathrm{~mol} / \mathrm{L})$, and the mixture was stirred at room temperature for $24 \mathrm{~h}$. The material was then collected by centrifugation and washed with deionized water several times. Following washing it was dried at $120^{\circ} \mathrm{C}$ for $12 \mathrm{~h}$. Finally, the dried material was further calcined under $10 \% \mathrm{O}_{2}$ in $\mathrm{Ar}$ (Nanjing Special Gases) at $400{ }^{\circ} \mathrm{C}$ for $2 \mathrm{~h}$ and then reduced under $10 \% \mathrm{H}_{2}$ in Ar (Nanjing Special Gases) at $300{ }^{\circ} \mathrm{C}$ for another $2 \mathrm{~h}$ to obtain the catalyst.

\subsection{Synthesis of $\mathrm{XAl} / \mathrm{Pt} / \mathrm{Al}_{2} \mathrm{O}_{3}$ catalysts}

ALD was carried out on a viscous flow reactor (GEMSTAR- $6^{\mathrm{TM}}$ Benchtop ALD, Arradiance) at a base pressure of 1.0 Torr. Ultra high purity $\mathrm{N}_{2}$ (Nanjing Special Gases, 99.999\%) was used as the carrier gas (200 mL/min). After loading the $\mathrm{Pt} / \mathrm{Al}_{2} \mathrm{O}_{3}$ catalyst into the ALD reactor, $\mathrm{Al}_{2} \mathrm{O}_{3} \mathrm{ALD}$ was performed by alternate exposure to trimethylaluminum (TMA, Sigma Aldrich, 99\%) and deionized water at $200{ }^{\circ} \mathrm{C}$ for different numbers of cycles. The timing sequence was 9,180 , 15 , and $180 \mathrm{~s}$ for TMA exposure, $\mathrm{N}_{2}$ purge, water exposure and $\mathrm{N}_{2}$ purge, respectively.

\subsection{Characterization}

The morphologies of the catalysts were characterized using transmission electron microscopy (TEM) (JOEL-2010, University of Science and Technology of China). The Pt loading of the $\mathrm{Pt} / \mathrm{Al}_{2} \mathrm{O}_{3}$ catalyst was determined to be $2 \%$ using inductively coupled plasma atomic emission spectroscopy (ICP-AES) (University of Science and Technology of China).

The Pt dispersions of $\mathrm{Pt} / \mathrm{Al}_{2} \mathrm{O}_{3}$ and alumina-coated $\mathrm{Pt} / \mathrm{Al}_{2} \mathrm{O}_{3}$ catalysts were evaluated using the $\mathrm{CO}$ chemisorption method on an AutoChem ${ }^{\mathrm{TM}}$ II 2920 Micromeritics instrument. After loading, the sample was first calcined under $10 \% \mathrm{O}_{2}$ in $\mathrm{He}$ at $300{ }^{\circ} \mathrm{C}$ for $2 \mathrm{~h}$, followed by reduction under $10 \% \mathrm{H}_{2}$ in $\mathrm{Ar}$ at 200 ${ }^{\circ} \mathrm{C}$ for another $1 \mathrm{~h}$. After cooling the sample to $50{ }^{\circ} \mathrm{C}$ in $\mathrm{He}, 10 \%$ $\mathrm{CO}$ in $\mathrm{He}$ was pulsed until saturation. All gases were provided by Nanjing Special Gases.

The diffuse reflectance infrared Fourier transform spec- 
troscopy (DRIFTS) CO chemisorption measurements were performed on a Nicolet iS10 spectrometer equipped with an MCT detector and a low temperature reaction cell (Praying Mantis Harrick). The sample was loaded into the cell and calcined under $10 \% \mathrm{O}_{2}$ in $\mathrm{He}$ at $300{ }^{\circ} \mathrm{C}$ for $2 \mathrm{~h}$, followed by reduction under $10 \% \mathrm{H}_{2}$ in $\mathrm{He}$ at $200{ }^{\circ} \mathrm{C}$ for another $1 \mathrm{~h}$. After cooling the sample to room temperature in an atmosphere of He, a background spectrum was collected. $10 \%$ CO in $\mathrm{He}(20$ $\mathrm{mL} / \mathrm{min}$ ) was then introduced into the cell. Finally, the sample was purged with $\mathrm{He}(20 \mathrm{~mL} / \mathrm{min})$ for $30 \mathrm{~min}$ to remove the gas phase CO. A DRIFTS spectrum was then collected at a resolution of $4 \mathrm{~cm}^{-1}$.

The DRIFTS pyridine chemisorption measurements were also performed using the Nicolet iS10 spectrometer. The sample was loaded into the cell and calcined under $10 \% \mathrm{O}_{2}$ in $\mathrm{He}$ at $300{ }^{\circ} \mathrm{C}$ for $1 \mathrm{~h}$. The cell was then cooled to room temperature under He and a background spectrum was collected. Following background collection, pyridine vapor was introduced into the cell, using He as a carrier, until the catalyst surface was saturated. Finally, the sample was purged with $\mathrm{He}(20 \mathrm{~mL} / \mathrm{min})$ for $45 \mathrm{~min}$ to remove gas phase and physisorbed pyridine. A DRIFTS spectrum was then collected at a resolution of $4 \mathrm{~cm}^{-1}$.

\subsection{Activity test}

\subsubsection{Glycerol hydrogenolysis}

Glycerol hydrogenolysis reaction was carried out in a 100-mL Parr autoclave at $220^{\circ} \mathrm{C}$ under a hydrogen pressure of 8.0 MPa. For each reaction test, $40 \mathrm{~g}$ of $20 \mathrm{wt} \%$ glycerol (Sinopharm Chemical Reagent Co., Ltd.) aqueous solution was used. The amount of $\mathrm{Pt} / \mathrm{Al}_{2} \mathrm{O}_{3}$ catalyst used was $450 \mathrm{mg}$, while the amount of alumina coated $\mathrm{Pt} / \mathrm{Al}_{2} \mathrm{O}_{3}$ catalyst was adjusted to provide the same Pt content. After loading the substrate and catalyst, the autoclave was purged 5 times using He (99.999\%) (Nanjing Special Gases, 99.999\%) to remove any air. The autoclave was then charged with ultrapure $\mathrm{H}_{2}$ (Nanjing Special Gases, 99.999\%). After the reactor was heated to $220^{\circ} \mathrm{C}, \mathrm{H}_{2}$ was pressurized to $8.0 \mathrm{MPa}$ and the reaction started after turning on stirring at a speed of $700 \mathrm{r} / \mathrm{min}$ to remove any mass transfer contribution. Following reaction the reactor was quickly cooled to room temperature. The gas phase products were collected in a gasbag and the liquid phase products were separated from the catalyst by filtration. All products were analyzed using a Shimadzu GC-2014 gas chromatograph equipped with an Rtx-1 capillary column and an auto-injector. The products identified were: 1,2-PD, 1,3-PD, 1-propanol (1-PO) and ethylene glycol (EG). The carbon balance for this reaction was approximately $94.9 \%$. The conversion of glycerol and product selectivity were calculated using the following equation:

Conversion $(\%)=($ moles of all products $/$ moles of glycerol charged) $\times 100 \%$

Selectivity $(\%)=$ (moles of product $/$ moles of all products $)$ $\times 100 \%$

\subsubsection{Acetol hydrogenation}

Acetol hydrogenation reaction was carried out in a $100-\mathrm{mL}$
Parr autoclave at $160^{\circ} \mathrm{C}$ under a hydrogen pressure of 4.0 MPa. For each reaction test, $50 \mathrm{~g}$ of $2 \mathrm{wt} \%$ acetol (Sinopharm Chemical Reagent Co., Ltd.) aqueous solution was used. The amount of $\mathrm{Pt} / \mathrm{Al}_{2} \mathrm{O}_{3}$ catalyst used was $75 \mathrm{mg}$, while the amount of $30 \mathrm{AlPt} / \mathrm{Al}_{2} \mathrm{O}_{3}$ catalyst was adjusted to provide the same $\mathrm{Pt}$ content. Following loading of the substrate and catalyst, the autoclave was purged 5 times using He (99.999\%) to remove any air. The autoclave was then charged with ultrapure $\mathrm{H}_{2}$ (99.999\%). Next, the reactor was heated to $160^{\circ} \mathrm{C}$; $\mathrm{H}_{2}$ was then pressurized to $4.0 \mathrm{MPa}$ and the reaction started after turning on stirring at a speed of $700 \mathrm{r} / \mathrm{min}$ to remove any mass transfer contribution. The products were analyzed using a Shimadzu GC-2014 gas chromatograph equipped with an Rtx-1 capillary column and an auto-injector. The only product identified was 1,2-PD.

The conversion of acetol was calculated using the following equation:

$$
\begin{aligned}
\text { Conversion }(\%)= & (\text { moles of acetol converted } / \text { moles of } \\
& \text { acetol charged }) \times 100 \%
\end{aligned}
$$

\section{Results and discussion}

A Pt/ $\mathrm{Al}_{2} \mathrm{O}_{3}$ catalyst with a Pt particle size of approximately 7 $\mathrm{nm}$ was synthesized using the wet-impregnation method (Fig. 1(b) and (d)) [28]. This technique uses synthesis of relatively larger Pt NPs to amplify the difference of metal-acid proximity before and after alumina overcoating. The Pt loading of $\mathrm{Pt} / \mathrm{Al}_{2} \mathrm{O}_{3}$ was determined to be $2 \mathrm{wt} \%$ by inductively coupled plasma atomic emission spectroscopy (ICP-AES). Fig. 1(c) and (e) show the morphology of the $\mathrm{Pt} / \mathrm{Al}_{2} \mathrm{O}_{3}$ sample coated with 30 cycles of alumina $\mathrm{ALD}\left(30 \mathrm{Al} / \mathrm{Pt} / \mathrm{Al}_{2} \mathrm{O}_{3}\right)$. ALD is known to provide uniform and conformal deposition on high-surface area materials [29,30]. In this case, the alumina overcoat uniformly encapsulated the Pt NPs with a thickness of $\sim 3.6 \mathrm{~nm}$, indicating a growth rate of $\sim 0.12 \mathrm{~nm}$ per ALD cycle, similar to what has been reported in the literature [31]. The Pt particle size distribution data shown in the insets of Fig. 1(d) and (e) suggest that Pt particle size did not visibly change during the ALD process, which is in line with our previous results [32]. Dispersion measurements using $\mathrm{CO}$ indicated that the $\mathrm{Al}_{2} \mathrm{O}_{3}$ coating layer was porous, although the Pt dispersion largely decreased from $21 \%$ to $2.9 \%, 2.5 \%$ and $2.2 \%$, for $10 \mathrm{Al} / \mathrm{Pt} / \mathrm{Al}_{2} \mathrm{O}_{3}$, $20 \mathrm{Al} / \mathrm{Pt} / \mathrm{Al}_{2} \mathrm{O}_{3}$, and $30 \mathrm{Al} / \mathrm{Pt} / \mathrm{Al}_{2} \mathrm{O}_{3}$, respectively (Table 1 ), consistent with our previous results [32]. On the other hand, DRIFTS measurements of pyridine chemisorption confirmed that only Lewis acid sites were presented in the $\mathrm{Pt} / \mathrm{Al}_{2} \mathrm{O}_{3}$, $5 \mathrm{Al} / \mathrm{Pt} / \mathrm{Al}_{2} \mathrm{O}_{3}$, and $30 \mathrm{Al} / \mathrm{Pt} / \mathrm{Al}_{2} \mathrm{O}_{3}$ samples. This is indicated by the pyridine vibration band of the 8 a mode at $1615 \mathrm{~cm}^{-1}$ (Fig. 1(f)) [33], which is consistent with the literature [34]. It is worth noting that the alumina overcoat deposited by ALD is amorphous [35], which is different from the support which is $\gamma$-phase.

Hydrogenolysis of glycerol was conducted in a Parr batch reactor at $220{ }^{\circ} \mathrm{C}$ with a hydrogen pressure of $8.0 \mathrm{MPa}$. After reaction for $120 \mathrm{~h}$, the uncoated $\mathrm{Pt} / \mathrm{Al}_{2} \mathrm{O}_{3}$ catalyst showed a glycerol conversion of $60 \%$ and selectivity to 1,2-PD of $45 \%$ (Fig. 2). 1-PO and EG were the major by-products, with selec- 

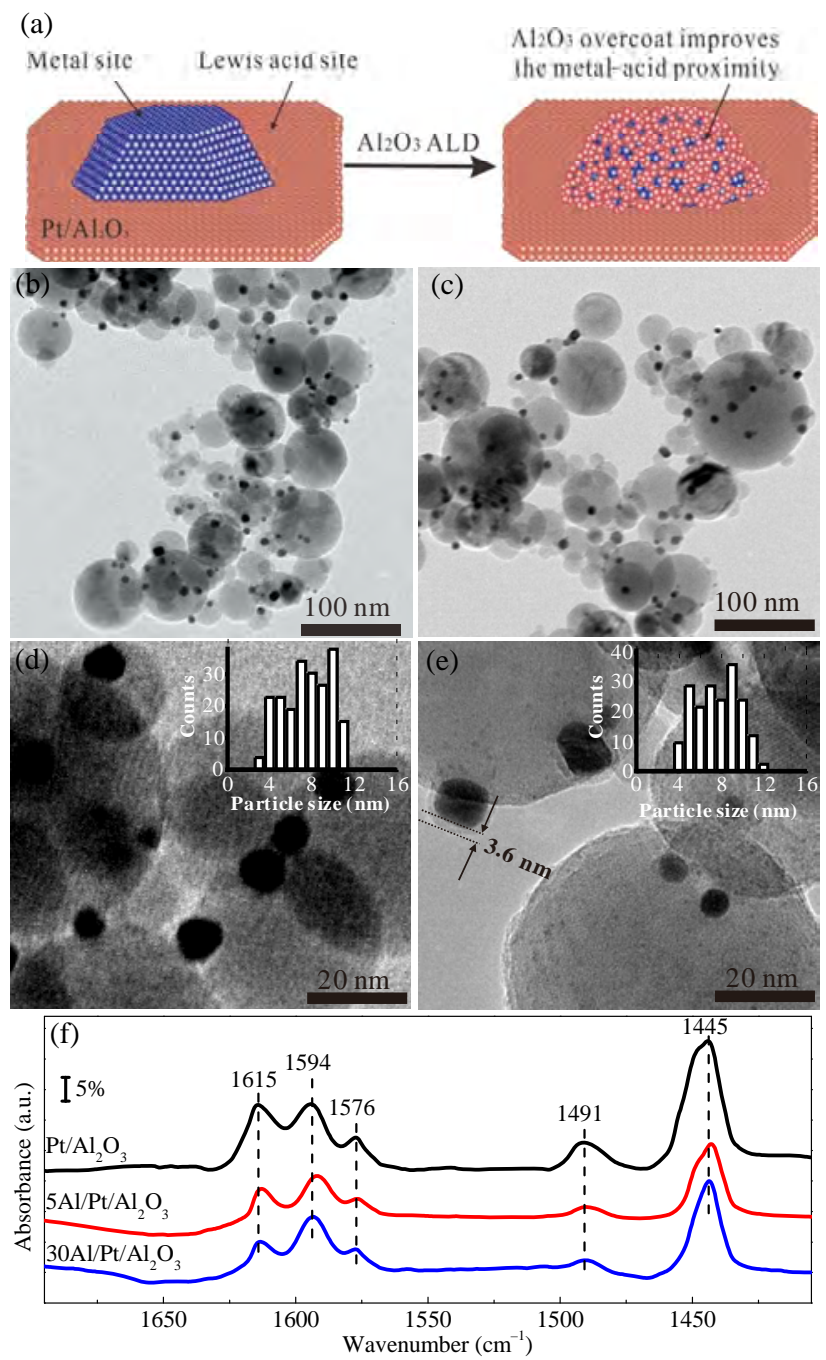

Fig. 1. (a) Schematic illustration of improving the metal-acid proximity of a $\mathrm{Pt} / \mathrm{Al}_{2} \mathrm{O}_{3}$ catalyst while keeping the overall acidity constant through acidic $\mathrm{Al}_{2} \mathrm{O}_{3}$ porous overcoat by ALD. TEM images of the uncoated $\mathrm{Pt} / \mathrm{Al}_{2} \mathrm{O}_{3}$ (b, d) and $30 \mathrm{Al} / \mathrm{Pt} / \mathrm{Al}_{2} \mathrm{O}_{3}$ (c, e) catalysts. The insets in (d) and (e) are the corresponding Pt particle size distribution. (f) DRIFT spectra of pyridine adsorption on $\mathrm{Pt} / \mathrm{Al}_{2} \mathrm{O}_{3}, 5 \mathrm{Al} / \mathrm{Pt} / \mathrm{Al}_{2} \mathrm{O}_{3}$ and $30 \mathrm{Al} / \mathrm{Pt} / \mathrm{Al}_{2} \mathrm{O}_{3}$ at room temperature.

Table 1

The Pt dispersions of different catalysts after different reaction time.

\begin{tabular}{lcc}
\hline Catalyst & Reaction time $(\mathrm{h})$ & Pt dispersion $(\%)$ \\
\hline & 0 & 21.0 \\
$\mathrm{Pt} / \mathrm{Al}_{2} \mathrm{O}_{3}$ & 12 & 20.0 \\
& 24 & 18.8 \\
& 48 & 14.6 \\
$10 \mathrm{Al} / \mathrm{Pt} / \mathrm{Al}_{2} \mathrm{O}_{3}$ & 0 & 2.9 \\
$20 \mathrm{Al} / \mathrm{Pt} / \mathrm{Al}_{2} \mathrm{O}_{3}$ & 0 & 2.5 \\
& 0 & 2.2 \\
$30 \mathrm{Al} / \mathrm{Pt} / \mathrm{Al}_{2} \mathrm{O}_{3}$ & 12 & 11.2 \\
& 24 & 9.5 \\
& 48 & 10.2 \\
\hline
\end{tabular}

tivities of $45 \%$ and $8.3 \%$, respectively. The selectivity to 1,3-PD was only $1.5 \%$. These results are expected given that there are only Lewis acid sites present on the alumina surface (Scheme 1

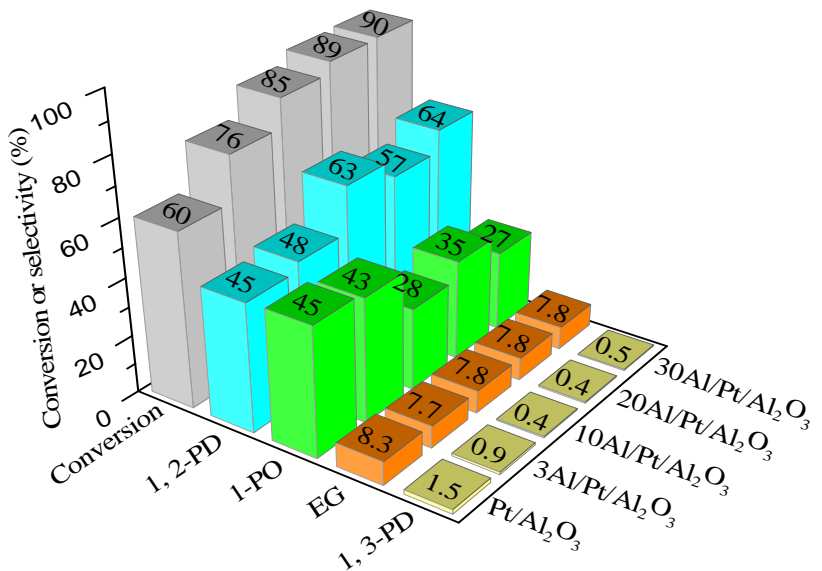

Fig. 2. Glycerol conversion and products selectivity on $\mathrm{Pt} / \mathrm{Al}_{2} \mathrm{O}_{3}$, $3 \mathrm{Al} / \mathrm{Pt} / \mathrm{Al}_{2} \mathrm{O}_{3}, 10 \mathrm{Al} / \mathrm{Pt} / \mathrm{Al}_{2} \mathrm{O}_{3}, 20 \mathrm{Al} / \mathrm{Pt} / \mathrm{Al}_{2} \mathrm{O}_{3}$, and $30 \mathrm{Al} / \mathrm{Pt} / \mathrm{Al}_{2} \mathrm{O}_{3}$ catalysts in hydrogenolysis of glycerol. Reaction conditions: $20 \mathrm{wt} \%$ glycerol aqueous solution $40 \mathrm{~g}$, catalyst $450 \mathrm{mg}, 220^{\circ} \mathrm{C}, 8.0 \mathrm{MPa}, 120 \mathrm{~h}$.

and Fig. 1(f)). After depositing 3 ALD cycles of alumina $\left(3 \mathrm{Al} / \mathrm{Pt} / \mathrm{Al}_{2} \mathrm{O}_{3}\right)$, the conversion increased to $76 \%$, while the product selectivity did not change significantly. Further increasing the number of ALD cycles, continuously increased glycerol conversion, which reached $90 \%$ on $30 \mathrm{Al} / \mathrm{Pt} / \mathrm{Al}_{2} \mathrm{O}_{3}$; meanwhile, the 1,2-PD selectivity also increased to $64 \%$. In contrast, the 1 -PO selectivity dropped to $27 \%$, while the selectivity to EG and 1,3-PD remained approximately constant. The data show that the presence of an alumina overcoat on Pt NPs considerably suppressed secondary hydrogenolysis of 1,2-PD to $1-\mathrm{PO}$.

Catalytic performance of the $\mathrm{Pt} / \mathrm{Al}_{2} \mathrm{O}_{3}$ and $30 \mathrm{Al} / \mathrm{Pt} / \mathrm{Al}_{2} \mathrm{O}_{3}$ catalysts was also compared after different reaction times. At low glycerol conversions (below 40\%), the selectivity to 1,2-PD on $\mathrm{Pt} / \mathrm{Al}_{2} \mathrm{O}_{3}$ was $\sim 65 \%$ (Fig. 3(a)). Increasing the conversion to $60 \%$ caused the selectivity to $1,2-\mathrm{PD}$ to decrease significantly to $45 \%$. Meanwhile, the 1 -PO selectivity increased from $\sim 22 \%$ to $45 \%$. The selectivity to other products showed negligible change throughout the entire reaction. On $30 \mathrm{Al} / \mathrm{Pt} / \mathrm{Al}_{2} \mathrm{O}_{3}$, the 1,2-PD selectivity was $\sim 76 \%$ at a glycerol conversion of $38 \%$ (Fig. 3(b)). Increasing the conversion to as high as $90 \%$ did not lead to a significant decrease in 1,2-PD selectivity, which remained at $64 \%$. The $1-\mathrm{PO}$ selectivity was only $27 \%$ at $90 \%$ conversion. It is worth noting that glycerol conversion was less than $1 \%$ on blank $\mathrm{Al}_{2} \mathrm{O}_{3}$ after $24 \mathrm{~h}$ under the same conditions.

Dispersion measurements revealed that the Pt dispersion of $\mathrm{Pt} / \mathrm{Al}_{2} \mathrm{O}_{3}$ decreased slightly to $15 \%$ from $21 \%$ after reaction for $48 \mathrm{~h}$ (Table 1). For $30 \mathrm{Al} / \mathrm{Pt} / \mathrm{Al}_{2} \mathrm{O}_{3}$, the Pt dispersion increased substantially from $2.2 \%$ to $11.2 \%$ after reaction for $12 \mathrm{~h}$, and subsequently remained stable. The initial turnover frequencies (TOFs) of $\mathrm{Pt} / \mathrm{Al}_{2} \mathrm{O}_{3}$ and $30 \mathrm{Al} / \mathrm{Pt} / \mathrm{Al}_{2} \mathrm{O}_{3}$ after reaction for $24 \mathrm{~h}$ were calculated according to the number of Pt surface atoms. We found that the TOF of $30 \mathrm{Al} / \mathrm{Pt} / \mathrm{Al}_{2} \mathrm{O}_{3}$ was $\sim 341 \mathrm{~h}^{-1}$, which was $\sim 2.8$ times higher than $\mathrm{Pt} / \mathrm{Al}_{2} \mathrm{O}_{3}\left(122 \mathrm{~h}^{-1}\right)$ as shown in Fig. $3(\mathrm{c})$.

The sintering of Pt NPs in both $\mathrm{Pt} / \mathrm{Al}_{2} \mathrm{O}_{3}$ and $30 \mathrm{Al} / \mathrm{Pt} / \mathrm{Al}_{2} \mathrm{O}_{3}$ samples was less pronounced after reaction for $120 \mathrm{~h}$, which might be due to the relatively large Pt particle size (Fig. 4). We 

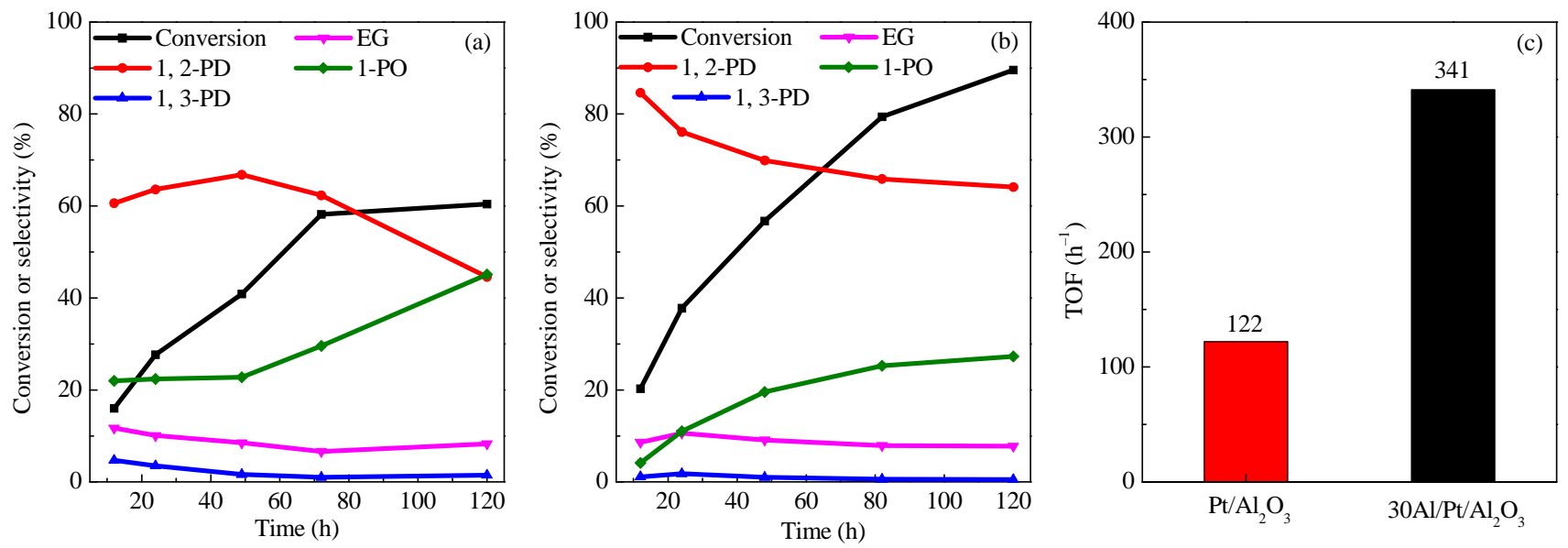

Fig. 3. Catalytic performance of $\mathrm{Pt} / \mathrm{Al}_{2} \mathrm{O}_{3}$ (a) and $30 \mathrm{Al} / \mathrm{Pt} / \mathrm{Al}_{2} \mathrm{O}_{3}$ (b) catalysts as a function of reaction time in the glycerol hydrogenolysis reaction. Reaction conditions: $20 \mathrm{wt} \%$ glycerol aqueous solution $40 \mathrm{~g}$, catalyst $450 \mathrm{mg}, 220^{\circ} \mathrm{C}, 8.0 \mathrm{MPa}$. (c) Initial TOFs of Pt/Al $\mathrm{O}_{3}$ and $30 \mathrm{Al} / \mathrm{Pt} / \mathrm{Al}_{2} \mathrm{O}_{3} \mathrm{catalysts}$.

found that the alumina overcoat in the used $30 \mathrm{Al} / \mathrm{Pt} / \mathrm{Al}_{2} \mathrm{O}_{3}$ samples was hardly detected by TEM (Fig. 4(c)-(f)) when compared with the TEM observation of the fresh catalyst (Fig. 1(e)). This supports the Pt dispersion increase during reaction. Nonetheless, we noticed that the Pt dispersion of the used $30 \mathrm{Al} / \mathrm{Pt} / \mathrm{Al}_{2} \mathrm{O}_{3}$ sample was still considerably lower than that of the uncoated $\mathrm{Pt} / \mathrm{Al}_{2} \mathrm{O}_{3}$ (Table 1). This suggests that there might be a small fraction of the $\mathrm{Al}_{2} \mathrm{O}_{3}$ overcoat remaining on the $\mathrm{Pt}$ NPs after subjection to the harsh reaction conditions.

DRIFTS CO chemisorption measurements were also carried out on the fresh and used $\mathrm{Pt} / \mathrm{Al}_{2} \mathrm{O}_{3}$ and $30 \mathrm{Al} / \mathrm{Pt} / \mathrm{Al}_{2} \mathrm{O}_{3}$ samples.

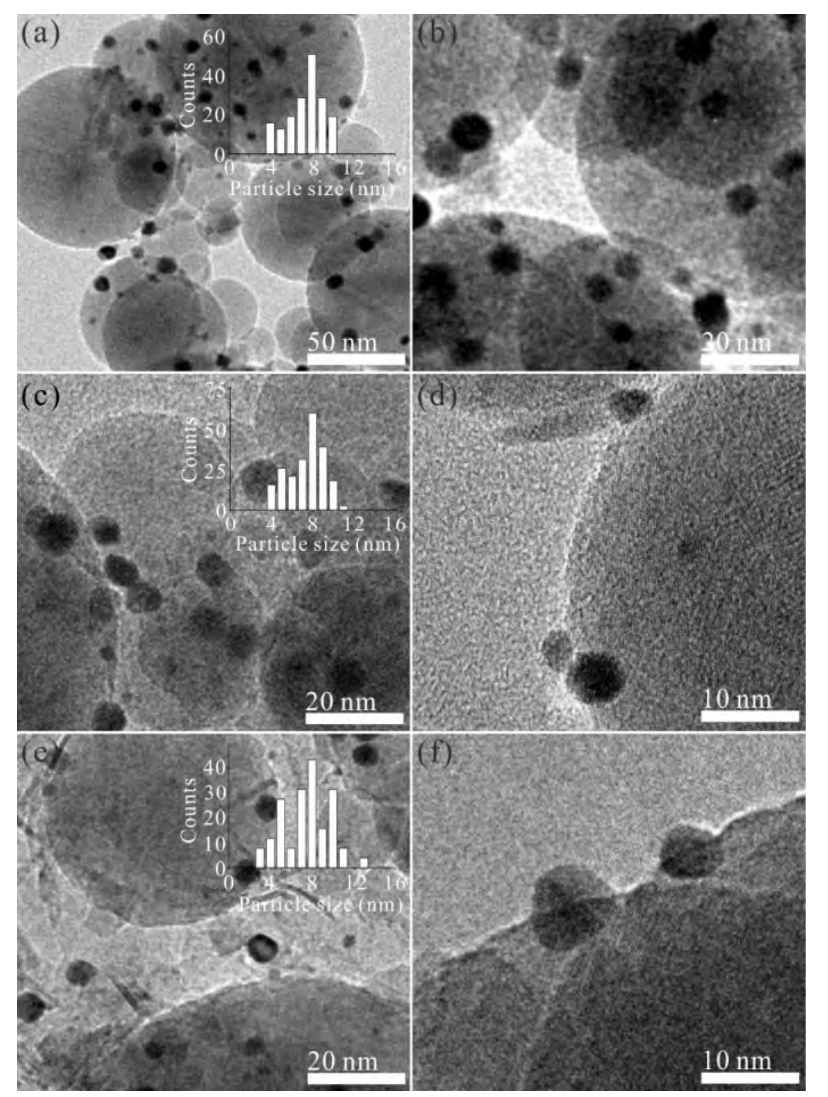

Fig. 4. TEM images of $\mathrm{Pt} / \mathrm{Al}_{2} \mathrm{O}_{3}$ after $120 \mathrm{~h}$ reaction $(\mathrm{a}, \mathrm{b}), 30 \mathrm{Al} / \mathrm{Pt} / \mathrm{Al}_{2} \mathrm{O}_{3}$ after $12 \mathrm{~h}$ reaction $(\mathrm{c}, \mathrm{d})$ and $30 \mathrm{Al} / \mathrm{Pt} / \mathrm{Al}_{2} \mathrm{O}_{3}$ after $120 \mathrm{~h}$ reaction $(\mathrm{e}, \mathrm{f})$.
The fresh $\mathrm{Pt} / \mathrm{Al}_{2} \mathrm{O}_{3}$ sample exhibited strong bands at 2093 and $2075 \mathrm{~cm}^{-1}$, which are assigned to CO linearly-bonded to Pt sites associated with relatively larger and smaller Pt NPs, respectively (Fig. 5(a)). The weaker band at $1833 \mathrm{~cm}^{-1}$ is assigned to bridge-bonded CO on Pt [36]. After reaction for $120 \mathrm{~h}$, the linear CO peak shifted slightly to $2088 \mathrm{~cm}^{-1}$, while the peak at 2075 $\mathrm{cm}^{-1}$ was no longer detected, which indicates that smaller Pt NPs may have aggregated during the reaction, although this was not obvious in the TEM image at the resolution as shown in Fig. 4(e). For the fresh $30 \mathrm{Al} / \mathrm{Pt} / \mathrm{Al}_{2} \mathrm{O}_{3}$ sample, the $\mathrm{CO}$ chemisorption peak was barely distinguishable (Fig. 5(b)), consistent with the dispersion measurement (Table 1). After reaction for $12 \mathrm{~h}$, the intensities of the CO peaks increased significantly, and the shapes of the $\mathrm{CO}$ chemisorption peaks were comparable to those of the peaks for the fresh uncoated $\mathrm{Pt} / \mathrm{Al}_{2} \mathrm{O}_{3}$ sample. We also observed an additional peak around $1963 \mathrm{~cm}^{-1}$. This new peak could be ascribed to bridge-bonded $\mathrm{CO}$ on $\mathrm{Pt}$ and $\mathrm{Al}$ atoms at the interface between the Pt NPs and the alumina overcoat [37-39]. As reaction time increased, the intensity of the peak at $1963 \mathrm{~cm}^{-1}$ increased, which is likely due to the formation of a
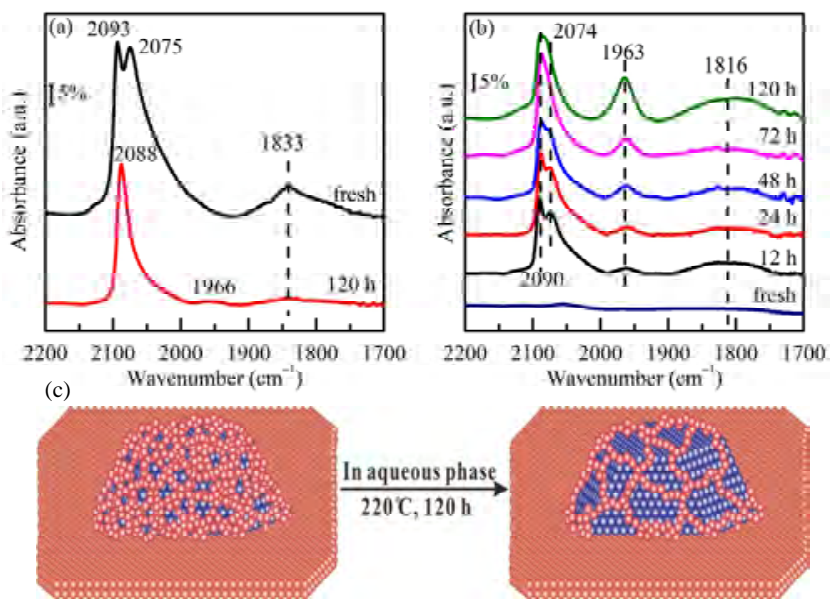

Fig. 5. DRIFT spectra of $\mathrm{CO}$ chemisorption on the fresh and used $\mathrm{Pt} / \mathrm{Al}_{2} \mathrm{O}_{3}$ (a) and $30 \mathrm{Al} / \mathrm{Pt} / \mathrm{Al}_{2} \mathrm{O}_{3}$ (b) at the $\mathrm{CO}$ saturation coverage. The reaction time was indicated. (c) Schematic illustration of the morphology change of $\mathrm{Al}_{2} \mathrm{O}_{3}$ overcoat under the severe reaction condition of glycerol hydrogenolysis. 


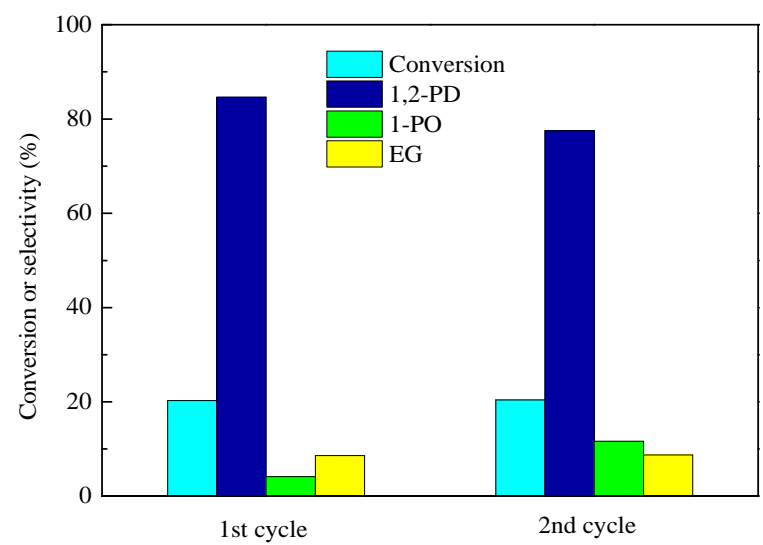

Fig. 6. Reuse of the $30 \mathrm{Al} / \mathrm{Pt} / \mathrm{Al}_{2} \mathrm{O}_{3}$ catalyst in the glycerol hydrogenolysis. Reaction conditions: $20 \mathrm{wt} \%$ glycerol aqueous solution $40 \mathrm{~g}$, catalyst $450 \mathrm{mg}, 220^{\circ} \mathrm{C}, 8.0 \mathrm{MPa}, 12 \mathrm{~h}$.

stronger Pt-alumina interaction. A weak peak at $1966 \mathrm{~cm}^{-1}$ was also observed for the used $\mathrm{Pt} / \mathrm{Al}_{2} \mathrm{O}_{3}$ sample (Fig. 5(a)). The much greater intensity of the peak at $1963 \mathrm{~cm}^{-1}$ for $30 \mathrm{Al} / \mathrm{Pt} / \mathrm{Al}_{2} \mathrm{O}_{3}(120 \mathrm{~h})$ confirmed that the area of the Pt-alumina interface was greater for $30 \mathrm{Al} / \mathrm{Pt} / \mathrm{Al}_{2} \mathrm{O}_{3}$ than for $\mathrm{Pt} / \mathrm{Al}_{2} \mathrm{O}_{3}$. It also suggests that the interaction between the ALD alumina overcoat and Pt is strong, although some of the alumina overcoat became detached from the Pt NPs under the severe reaction conditions, as shown in the schematic illustration in Fig. 5(c).

To verify whether the leached alumina species in solution had a significant impact on the activity improvement, the $30 \mathrm{Al} / \mathrm{Pt} / \mathrm{Al}_{2} \mathrm{O}_{3}$ sample after reaction for $12 \mathrm{~h}$ was centrifuged and washed five times and then recycled under identical reaction conditions. As shown in Fig. 6, we found that the activity of the used catalyst did not change considerably, and only a slight decrease in the selectivity to 1,2-PD was observed. The improvements in activity were therefore not due to the presence of leached alumina species in solution but to the Pt-alumina interface. This is not unexpected given that the glycerol conversion on blank alumina was negligible after $120 \mathrm{~h}$ (not shown).
To further understand the role of the alumina overcoat on the activity enhancement (Fig. 4(c) and (e)), the used $\mathrm{Pt} / \mathrm{Al}_{2} \mathrm{O}_{3}$ $(24 \mathrm{~h})$ and $30 \mathrm{Al} / \mathrm{Pt} / \mathrm{Al}_{2} \mathrm{O}_{3}(24 \mathrm{~h})$ samples were evaluated using acetol hydrogenation, since acetol is the likely reaction intermediate according to the literature [18]. As shown in Fig. 7, we found that the activity of $30 \mathrm{Al} / \mathrm{Pt} / \mathrm{Al}_{2} \mathrm{O}_{3}(24 \mathrm{~h})$ was slightly lower than that of $\mathrm{Pt} / \mathrm{Al}_{2} \mathrm{O}_{3}(24 \mathrm{~h})$. However, both were approximately one order magnitude higher than the activities for the glycerol hydrogenolysis reaction, despite the reaction conditions $\left(160{ }^{\circ} \mathrm{C}\right.$ and 4.0 MPa hydrogen pressure) being much milder than in the glycerol hydrogenolysis case. These results strongly indicate the following. (1) The alumina overcoat on $\mathrm{Pt}$ NPs does not promote the acetol hydrogenation reaction, in line with our previous observation for ALD alumina coated $\mathrm{Pd} / \mathrm{Al}_{2} \mathrm{O}_{3}$ catalyst for the selective hydrogenation of 1,3-butadiene [32]. (2) The rate-determining step in the glycerol hydrogenolysis reaction is not the acetol hydrogenation reaction, but the dehydration step, again consistent with the literature where dehydration was suggested to be the rate-determining step, requiring relatively higher reaction temperatures than the following hydrogenation [40]. Therefore, the observed activity improvement resulting from the alumina overcoat in the hydrogenolysis of glycerol could be attributed to the enhancement of the dehydration reaction step, which requires acidic function. Since the overall $\mathrm{Pt} / \mathrm{Al}_{2} \mathrm{O}_{3}$ catalyst acidity did not change considerably (Fig. 1(f)), the improved metal-acid proximity occasioned by the alumina overcoat is very likely responsible for the activity enhancement through the synergetic effect [12].

A Pt $/ \mathrm{Al}_{2} \mathrm{O}_{3}$ catalyst with a smaller Pt particle size of $\sim 2 \mathrm{~nm}$ was also synthesized. For glycerol hydrogenolysis, this sample showed selectivity to 1,2-PD of approximately $78 \%$ at a glycerol conversion of $22 \%$, which was considerably higher than that of the $7 \mathrm{~nm}$ Pt sample (Fig. 3(a)). This demonstrates that glycerol hydrogenolysis is a structure sensitive reaction, and decreasing Pt particle size suppresses the secondary hydrogenolysis of 1,2-PD to 1-PO. This result is consistent with a previous study where the yield of 1-PO and degradation products in-
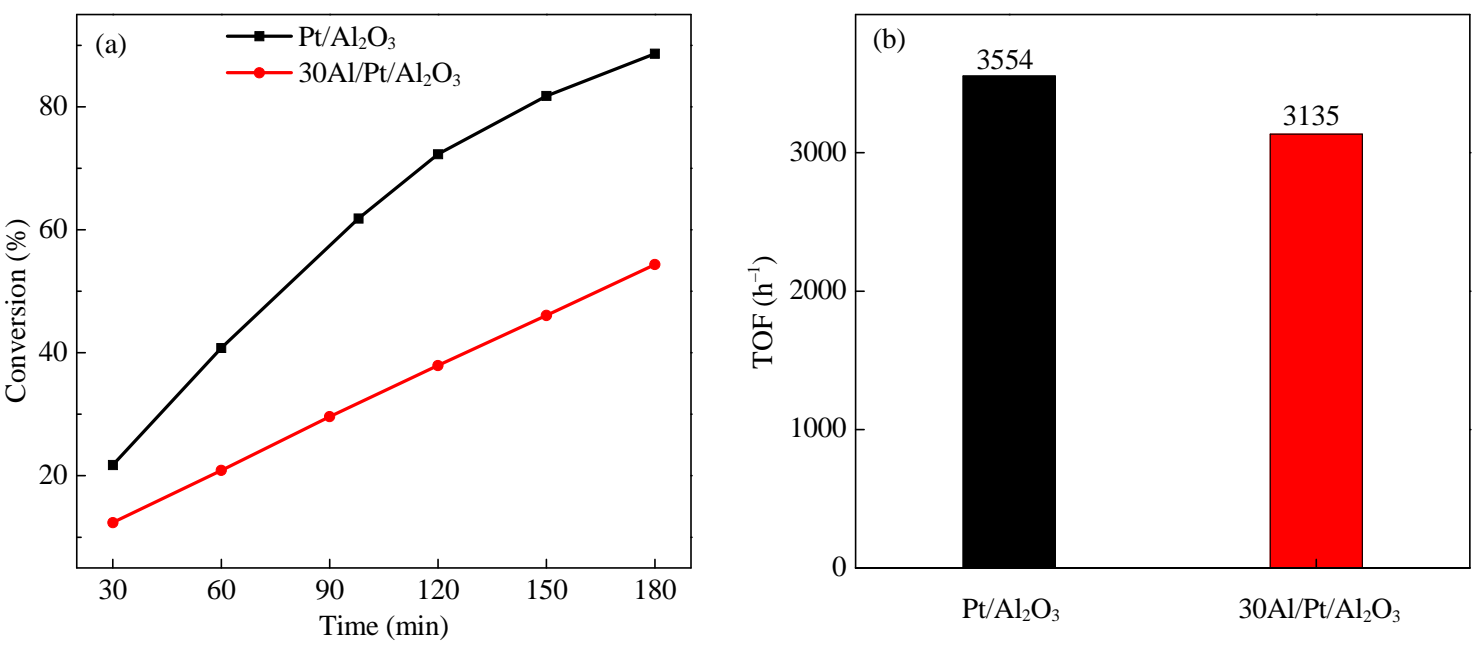

Fig. 7. (a) Catalytic performance of used $\mathrm{Pt} / \mathrm{Al}_{2} \mathrm{O}_{3}$ and $30 \mathrm{Al} / \mathrm{Pt} / \mathrm{Al}_{2} \mathrm{O}_{3}$ catalysts as a function of reaction time in the acetol hydrogenation reaction. Reaction conditions: 2 wt $\%$ acetol aqueous solution $50 \mathrm{~g}, 160{ }^{\circ} \mathrm{C}, 4.0 \mathrm{MPa}$. (b) Initial TOFs of Pt/ $\mathrm{Al}_{2} \mathrm{O}_{3}$ and $30 \mathrm{Al} / \mathrm{Pt} / \mathrm{Al}_{2} \mathrm{O}_{3}$ catalysts. 
creased on aggregated Pt catalyst in the $2^{\text {nd }}$ run of recycling testing [41]. Therefore, the increase in 1,2-PD selectivity caused by the alumina overcoat might be due to a geometric effect, where the surface of the Pt NPs is divided into smaller enclaves by the porous alumina overcoat, approximately simulating a decrease of Pt particle size.

\section{Conclusions}

In this work, we have demonstrated that precisely controlled alumina overcoating of $\mathrm{Pt} / \mathrm{Al}_{2} \mathrm{O}_{3}$ catalyst using ALD improved both activity and selectivity to 1,2-PD in the aqueous-phase hydrogenolysis of glycerol. Our work provides solid evidence that close metal-acid proximity enhances bifunctionality, thus improving the catalytic activity. To the best of our knowledge, this is the first work to investigate close metal-acid proximity by applying an alumina overcoat, without varying the overall catalyst acidity. Finally, our work highlights a new method for investigating the metal-acid proximity effect in other catalytic reaction systems.

\section{References}

[1] N. Musselwhite, K. Na, S. Alayoglu, G. A. Somorjai, J. Am. Chem. Soc., 2014, 136, 16661-16665.

[2] C. A. A. Monteiro, D. Costa, J. L. Zotin, D. Cardoso, Fuel, 2015, 160, 71-79.

[3] F. Anaya, L. Zhang, Q. H. Tan, D. E. Resasco, J. Catal., 2015, 328, 173-185.

[4] P. Barbaro, F. Liguori, N. Linares, C. M. Marrodan, Eur. J. Inorg. Chem., 2012, 2012, 3807-3823.

[5] D. M. Alonso, S. G. Wettstein, J. A. Dumesic, Chem. Soc. Rev., 2012, 41, 8075-8098.

[6] P. B. Weisz, Adv. Catal., 1962, 13, 137-190.

[7] J. E. Samad, J. Blanchard, C. Sayag, C. Louis, J. R. Regalbuto, J. Catal., 2016, 342, 203-212.

[8] W. Knaeble, E. Iglesia, J. Catal., 2016, 344, 817-830.
[9] J. Francis, E. Guillon, N. Bats, C. Pichon, A. Corma, L. J. Simon, Appl. Catal. A, 2011, 409, 140-147.

[10] M. Balaraju, V. Rekha, P. S. S. Prasad, B. L. A. P. Devi, R. B. N. Prasad, N. Lingaiah, Appl. Catal. A, 2009, 354, 82-87.

[11] K. Fujimoto, K. Maeda, K. Aimoto, Appl. Catal. A, 1992, 91, 81-86.

[12] J. Cejka, Introduction to zeolite science and practice, Elsevier, 2007.

[13] J. Kim, W. Kim, Y. Seo, J. C. Kim, R. Ryoo, J. Catal., 2013, 301, 187-197.

[14] J. Zecevic, K. P. de Jong, G. Vanbutsele, J. A. Martens, Nature, 2015, $528,245-248$.

[15] A. C. Alba-Rubio, B. J. O'Neill, F. Y. Shi, C. Akatay, C. Canlas, T. Li, R. Winans, J. W. Elam, E. A. Stach, P. M. Voyles, J. A. Dumesic, ACS Catal., 2014, 4, 1554-1557.

[16] M. A. Dasari, P. P. Kiatsimkul, W. R. Sutterlin, G. J. Suppes, Appl. Catal. A, 2005, 281, 225-231.

[17] J. ten Dam, U. Hanefeld, ChemSusChem, 2011, 4, 1017-1034.

[18] A. Alhanash, E. F. Kozhevnikova, I. V. Kozhevnikov, Appl. Catal. A, 2010, 378, 11-18.

[19] D. D. Falcone, J. H. Hack, A. Y. Klyushin, A. Knop-Gericke, R. Schlögl, R. J. Davis, ACS Catal., 2015, 5, 5679-5695.

[20] S. García-Fernández, I. Gandarias, J. Requies, M. B. Güemez, S. Bennici, A. Auroux, P. L. Arias, J. Catal., 2015, 323, 65-75.

[21] W. Oberhauser, C. Evangelisti, R. P. Jumde, R. Psaro, F. Vizza, M. Bevilacqua, J. Filippi, B. F. Machado, P. Serp, J. Catal., 2015, 325, 111-117.

[22] E. P. Maris, R. J. Davis, J. Catal., 2007, 249, 328-337.

[23] Y. Shinmi, S. Koso, T. Kubota, Y. Nakagawa, K. Tomishige, Appl. Catal. B, 2010, 94, 318-326.

[24] C. H. Deng, X. Z. Duan, J. H. Zhou, X. G. Zhou, W. K. Yuan, S. L. Scott, Catal. Sci. Technol., 2015, 5, 1540-1547.

[25] F. Mauriello, H. Ariga, M. G. Musolino, R. Pietropaolo, S. Takakusagi, K. Asakura, Appl. Catal. B, 2015, 166, 121-131.

[26] J. Wang, X. C. Zhao, N. Lei, L. Li, L. L. Zhang, S. T. Xu, S. Miao, X. L. Pan, A. Q. Wang, T. Zhang, ChemSusChem, 2016, 9, 784-790.

[27] Y. Nakagawa, Y. Shinmi, S. Koso, K. Tomishige, J. Catal., 2010, 272, 191-194.

[28] I. Son, M. Shamsuzzoha, A. M. Lane, J. Catal., 2002, 210, 460-465.

[29] J. L. Lu, J. W. Elam, P. C. Stair, Surf. Sci. Rep., 2016, 71, 410-472.

[30] S. M. George, Chem. Rev., 2010, 110, 111-131.

[31] H. B. Zhang, Y. Lei, A. J. Kropf, G. H. Zhang, J. W. Elam, J. T. Miller, F.

\section{Graphical Abstract}

Chin. J. Catal., 2017, 38: 1237-1244 doi: 10.1016/S1872-2067(17)62859-6

\section{Acidic alumina overcoating on platinum nanoparticles: Close metal-acid proximity enhances bifunctionality for glycerol hydrogenolysis}

Hongyi Du, Si Chen, Hengwei Wang, Junling Lu*

University of Science and Technology of China

Deposition of $\mathrm{Al}_{2} \mathrm{O}_{3}$ on $\mathrm{Pt} / \mathrm{Al}_{2} \mathrm{O}_{3}$ catalyst using $\mathrm{ALD}$ can significantly enhance the activity and selectivity to 1,2-propanediol in the hydrogenolysis of glycerol through the metal-acid proximity effect.

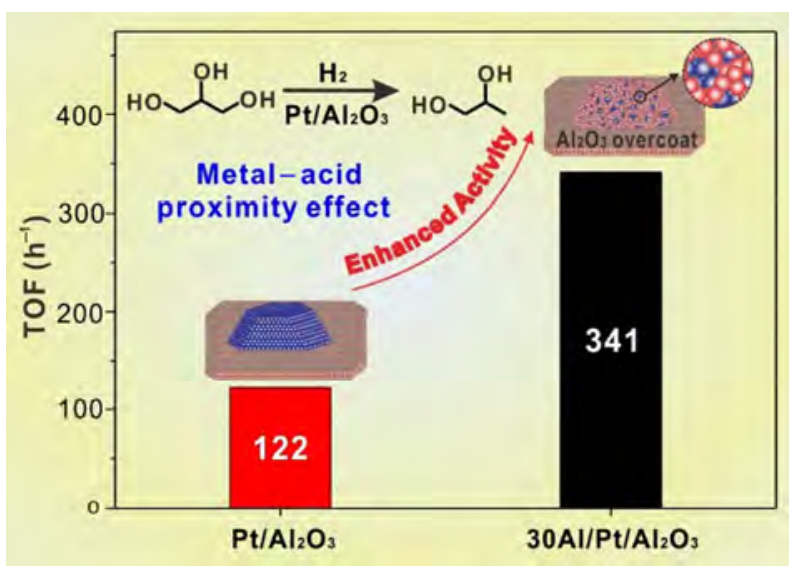


Sollberger, F. Ribeiro, M. C. Akatay, E. A. Stach, J. A. Dumesic, C. L. Marshall, J. Catal., 2014, 317, 284-292.

[32] H. Yi, H. Y. Du, Y. L. Hu, H. Yan, H. L. Jiang, J. L. Lu, ACS Catal., 2015, 5, 2735-2739.

[33] G. Busca, Catal. Today, 1998, 41, 191-206.

[34] T. H. Ballinger, J. T. Yates, Langmuir, 1991, 7, 3041-3045.

[35] V. Miikkulainen, M. Leskelä, M. Ritala, R. L. Puurunen, J. Appl. Phys., 2013, 113, 021301/1-021301/101.

[36] J. L. Lu, K. B. Low, A. Nicholls, Y. Lei, J. A. Libera, J. W. Elam, P. C. Stair, Nat. Commun., 2014, 5, 3264.

[37] B. T. Qiao, A. Q. Wang, X. F. Yang, L. F. Allard, Z. Jiang, Y. T. Cui, J. Y.
Liu, J. Li, T. Zhang, Nat. Chem., 2011, 3, 634-641.

[38] D. Ferri, T. Bürgi, A. Baiker, Phys. Chem. Chem. Phys., 2002, 4, 2667-2672.

[39] O. Pozdnyakova, D. Teschner, A. Wootsch, J. Krohnert, B. Steinhauer, H. Sauer, L. Toth, F. C. Jentoft, A. Knop-Gericke, Z. Paal, R. Schlogl, J. Catal., 2006, 237, 1-16.

[40] M. Akiyama, S. Sato, R. Takahashi, K. Inui, M. Yokota, Appl. Catal. A, 2009, 371, 60-66.

[41] J. ten Dam, K. Djanashvili, F. Kapteijn, U. Hanefeld, ChemCatChem, 2013, 5, 497-505.

\title{
酸性 $\mathrm{Al}_{2} \mathrm{O}_{3}$ 层包裏Pt纳米颗粒：增强的金属-酸性双功能协同效应 提高其甘油氢解反应催化性能
}

\author{
杜洪仪, 陈 飔, 王恒伟, 路军岭* \\ 中国科学技术大学化学物理系, 微尺度物质科学国家实验室(筹), 能量转换材料中国科学院重点实验室, \\ 能源材料化学协同创新中心, 安徽合肥230026
}

\begin{abstract}
摘要: 同时含有金属和酸性位点的双功能催化剂已广泛用于石油加氢裂解和可再生生物质转化中. 这两种位点之间的距 离对双功能协同作用起着至关重要的作用, 进而影响催化剂的活性与选择性. 近年来, 由生物质转化生产生物燃料和化学 品得到了广泛的关注. 相比于石油裂解工艺, 金属-酸性位点临近效应在生物质转化反应中鲜有报道. 甘油是来自生物柴 油生产过程中的廉价副产物(约总产量的 10\%). 通过选择性氢解将其转化为具有高附加价值的化学品如1,2-丙二醇和1,3丙二醇, 这是提高其附加值的主要途径. 甘油氢解包含脱水与加氢两个过程, 分别发生于酸性位点与金属位点上. 根据文 献报道, Lewis酸位点倾向于进攻甘油端位的羟基, 生成中间产物丙酮醇, 而Brønsted酸则更易进攻甘油中间位的羟基产生 3-着基丙醛; 随后两者进一步加氢分别生成1,2-丙二醇和1,3-丙二醇.

负载型金属催化剂广泛应用于甘油氢解反应中, 在金属催化剂中添加酸性助剂能显著提高催化剂的活性. 大量研究 表明, 无论是将酸性物种添加到金属颗粒表面或者是载体上甚至是简单的物理混合,均能有效提升催化剂的催化性能. 然 而据我们所知, 金属-酸性位点之间的临近效应还未在甘油氢解反应中报道过. 本文利用原子层沉积技术 $(\mathrm{ALD})$ 在 $\mathrm{Pt} / \mathrm{Al}_{2} \mathrm{O}_{3}$ 催化剂表面精确沉积了一层酸性多孔的氧化铝包裹层, 同时提高了 Pt催化剂的活性与 $1,2-$ 丙二醇选择性; 我们进一步通过 高分辨透射电镜(HRTEM)、一氧化碳吸附漫反射红外光谱(CO DRIFTS)、吡啶DRIFTS等手段研究了 $\mathrm{Al}_{2} \mathrm{O}_{3}$ 包裹层造成催化 活性提升的原因.
\end{abstract}

30个ALD周期氧化铝包裹后的催化剂具有最高的活性与选择性, HRTEM观测到催化剂中的Pt纳米颗粒的尺寸为7 $\mathrm{nm}$, 氧化铝包裹层厚度为 $3.6 \mathrm{~nm}$. 与未包裹的 $\mathrm{Pt} / \mathrm{Al}_{2} \mathrm{O}_{3}$ 催化剂相比, 沉积在 $\mathrm{Pt}$ 纳米颗粒上的酸性 $\mathrm{Al}_{2} \mathrm{O}_{3}$ 与 $\mathrm{Pt}$ 颗粒形成更多的 金属-酸性位点界面, 从而提升了 $\mathrm{Pt}$ 与 $\mathrm{Al}_{2} \mathrm{O}_{3}$ 酸性位点的亲密性. 由于生长的氧化铝薄膜与载体氧化铝为相同物种, 因此催 化剂包裹前后总体的酸度并未发生明显改变, 与吡啶化学吸附实验结果相一致. TEM测试发现, 氧化铝包裹层在催化反应 测试后会发生部分脱落. CO DRIFTS结果同样表明, 随着反应时间的增加, Pt上CO的吸收峰逐渐增强, 再次证实了Pt颗粒 表面包裹层的脱落; 但还发现一个位于 $1963 \mathrm{~cm}^{-1}$ 的新CO吸附峰. 该峰可归属于吸附于 $\mathrm{Pt}$ 与 $\mathrm{Al}_{2} \mathrm{O}_{3}$ 包裹层界面的桥式CO.

此外, 我们对其丙酮醇中间产物做了加氢反应的对比实验. 结果表明 $\mathrm{Al}_{2} \mathrm{O}_{3}$ 包裹层对 $\mathrm{Pt}$ 的加氢性能并未增加, 说明甘油 氢解反应的速控步骤是脱水. 因此, 我们初步认为, $\mathrm{Al}_{2} \mathrm{O}_{3}$ 包裹对甘油氢解反应活性的提高是通过其酸性而促进甘油脱水反 应所致. 我们还研究了 Pt尺寸效应对甘油氢解反应的影响, 发现小颗粒Pt对1,2-丙二醇的选择性比大颗粒更高, 而活性更 低, 这表明甘油氢解是一个结构敏感反应. 因此, $\mathrm{Al}_{2} \mathrm{O}_{3}$ 包裹层对 1 , 2-丙二醇选择性的提高可能是由于几何效应造成的, $\mathrm{Pt}$ 颗粒表面被 $\mathrm{Al}_{2} \mathrm{O}_{3}$ 包裹层分割为许多 $\mathrm{Pt}$ 聚集体, 类似于减小颗粒尺寸, 从而提高了反应选择性.

关键词: 金属-酸性位点临近效应; 甘油氢解; 铂催化剂; 原子层沉积; 氧化物包裹

收稿日期: 2017-04-15. 接受日期: 2017-05-09. 出版日期: 2017-07-05.

*通讯联系人. 电话：(0551)63600359; 电子信箱：junling@ustc.edu.cn

基金来源：国家自然科学基金(51402283, 21473169); 青年千人计划; 中央高校基本科研业务费专项资金资助(WK2060030017).

本文的英文电子版由Elsevier出版社在ScienceDirect上出版(http://www.sciencedirect.com/science/journal/18722067). 